\title{
PENERAPAN MODEL PEMBELAJARAN KOOPERATIF TIPE TPS UNTUK MENINGKATKAN HASIL BELAJAR PKn SISWA MATERI MENGHARGAI DAN MENAATI KEPUTUSAN BERSAMA DI KELAS V SDN 7 KABANGKA KABUPATEN MUNA
}

\author{
Salmina $^{1, a)}$, Sakka Hasan ${ }^{2}$ \\ ${ }^{1}$ Alumni Jurusan Pendidikan Guru Sekolah Dasar, FKIP Universitas Halu Oleo, \\ J1. H.E.A. Mokodompit Kendari 93232, Indonesia \\ ${ }^{2}$ Dosen FKIP Universitas Halu Oleo, Jl. H.E.A. Mokodompit Kendari 93232, \\ Indonesia \\ a)e-mail: armasalmina20@yahoo.co.id
}

\begin{abstract}
ABSTRAK
Penelitian ini bertujuan untuk meningkatkan hasil belajar siswa, aktivitas mengajar guru, dan aktivitas belajar siswa pada mata pelajaran PKn materi Menghargai dan Menaati Keputusan Bersama melalui penrapan Model Pembelajaran Kooperatif Tipe Think Pair Share (TPS). Penelitian ini menerapkan desain penelitian tindakan kelas dengan subyek penelitian siswa kelas V SDN 7 Kabangka Kabupaten Muna. Hasil penelitian menunjukkan bahwa presentase ketuntasan hasil belajar siswa siklus I adalah 58,33\% dengan nilai rata-rata 69,58 meningkat menjadi 83,33\% pada siklus II dengan nilai rata-rata 81,66 . Di samping itu, terjadi peningkatan aktivitas mengajar guru dari siklus I $84,21 \%$ menjadi $92,10 \%$. Pada hasil observasi aktivitas belajar siswa pada siklus I mencapai $81,81 \%$ meningkat menjadi $90,90 \%$.
\end{abstract}

Kata kunci: Hasil Belajar, Model Pembelajaran Kooperatif Tipe TPS

\author{
LEARNINGS MODEL IMPLEMENT KOOPERATIF TPS'S TYPE TO INCREASE PKn's \\ STUDYING RESULT STUDENT MATERIAL PRICES AND ABIDE BY DECISION WITH AT \\ CLASS V SDN 7 KABANGKA MUNA'S REGENCIES
}

\begin{abstract}
This study aims to improve student learning outcomes, teacher teaching activities, and student learning activities in material Civics subjects. Respect and Comply with Joint Decisions through the adoption of Cooperative Learning Models Type Think Pair Share (TPS). This study applies a classroom action research design with research subjects of fifth grade students of Kabangka SDN 7 Muna Regency. The results showed that the percentage of completeness of learning outcomes of the first cycle students was $58.33 \%$ with an average value of 69.58 increasing to $83.33 \%$ in cycle II with an average value of 81.66. In addition, there was an increase in teacher teaching activities from cycle I $84.21 \%$ to $92.10 \%$. The results of observation of student learning activities in the first cycle reached $81.81 \%$ increasing to $90.90 \%$.
\end{abstract}

\section{Keyword: : Learning Outcomes, TPS Type Cooperative Learning Models}

\section{Pendahuluan}

Pendidikan merupakan salah satu bentuk kegiatan dalam kehidupan manusia, yang berasal dari hal-hal yang bersifat aktual menuju pada hal-hal yang ideal. Hal-hal yang bersifat ideal berhubungan dengan cita-cita secara langsung atau tidak langsung bertujuan pada sosok yang diinginkan, ini semua berhubungan dengan tujuan pendidikan dan tujuan hidup (Mulyaharjo, 2004: 20). Dalam 
perspektif luas pendidikan merupakan upaya memanusiakan manusia agar menjadi manusia yang sebenar-benarnya manusia.

Mata pelajaran PKn pada dasarnya bertujuan untuk mengembangkan karakter utamanya dalam menanamkan moral, adab, dan etika siswa sesuai ideologi bangsa Indonesia baik di sekolah maupun di luar sekolah. Guru sebagai agen pendidikan perlu selalu meningkatkan kompetensi melalui inovasi pembelajaran yang berpusat pada siswa sehingga siswa aktif dan guru menjadi kreatif. Kurangnya motivasi guru dalam melakukan inovasi pembelajaran mengakibatkan banyak siswa yang memiliki minat dan motivasi di bawah rata-rata dalam usahanya untuk memahami pembelajaran PKn.

Berdasarkan hasil observasi awal pada tanggal 11 November 2015 bahwa dari hasil belajar siswa kelas V SD Negeri 7 Kabangka pada semester II ( genap) materi Pokok Menghargai dan Menaati Keputusan Bersama tahun 2014/2015 masih terdapat banyak siswa yang belum mencapai KKM yang telah ditetapkan oleh sekolah yaitu 70 , hanya 5 dari 12 siswa atau 41,66 \% siswa kelas $\mathrm{V}$ yang memperoleh nilai ulangan di atas 70 dan sisanya memperoleh nilai di bawah 70 dengan nilai rata- rata 61,66.

Untuk menyelesaikan permasalah tersebut di atas, maka peneliti tertarik untuk menerapkan Model Pembelajaran Kooperatif tipe Think Pair Share (TPS) untuk meningkaatkan hasil belajar siswa di kelas V SD Negeri 7 Kabangka pada semester II (genap) dengan mengadakan Penelitian Tindakan Kelas (PTK) yang berjudul, " Penerapan Model Pembelajaran Kooperatif Tipe Think Pair Share (TPS) Untuk Meningkatkan Hasil Belajar Siswa Pada Mata Pelajaran PKn Materi Menghargai dan Menaati Keputusan Bersama di Kelas V SD Negeri 7 Kabangka Kabupaten Muna".

Berdarkan hasil penelitian Irnawati (2015), dengn judul “ Meningkatkan hasil belajar PKn pada materi keputusan bersama melalui penerapan model pembelajaran Kooperatif tipe Think Pair Share (TPS) pada siswa kelas V SD Negeri Totombe Jaya Kecamatan Sampara yang menunjukkan bahwa hasil belajar pada siklus I dengan nilai rata-rata 67,49 dan terjadi peningkatan pada siklus II dengan nilai rata-rata yaitu 80,27, maka rumusan masalah dalam penelitian ini adalah Apakah penerapan Model Pembelajaran Kooperatif tipe Think Pair Share (TPS) dapat meningkatkan hasil belajar siswa, aktivitas mengajar guru, dan aktivitas belajar siswa pada mata pelajaran PKn materi Menghargai dan Menaati Keputusan Bersma di kelas V SD Negeri 7 Kabangka?

Penelitian ini bertujuan untuk Untuk meningkatkan hasil belajar siswa, aktivitas mengajar guru, dan aktivitas belajar siswa pada materi Menghargai dan Menaati Keputusan Bersama dengan menggunakan Model Pembelajaran Kooperatif tipe Think Pair Share (TPS) di kelas V SD Negeri 7 Kabangka.

Hasil dari penelitian ini diharapkan dapat memberikan informasi dalam dunia pendidikan berupa gambaran mengenai sebuah teori yang menyatakan bahwa peningkatan hasil belajar PKn pada materi Menghargai dan Menaati Keputusan Bersama dapat dilakukan dengan menggunakan model pembelajaran kooperatif tipe Think Pair Share (TPS).

\section{METODE PENELITIAN}

Jenis penelitian ini adalah penelitian tindakan kelas (Classroom Action Research). Penelitian tindakan kelas berasal dari bahasa Inggris yaitu Clasroom Action Research yang berarti penelitian yang dilakukan pada sebuah untuk mengetahui akibat tindaka yang diterapkan pada suatu subyek penelitian di kelas tersebut (Kardiawarman dalam Paizaludin dan Ermalinda, 2013: 6).

Penelitian Tindakan Kelas (PTK) ini dilaksanakan secara bersama-sama/kolaborasi antara peneliti dan guru di kelas V SDN 7 Kabangka Kabupaten Muna pada semester II (genap) tahun pelajaran 2015/2016. Subjek penelitian ini adalah guru dan siswa kelas $\mathrm{V}$ SDN 7 Kabangka tahun ajaran 2015/2016 yang berjumlah 12 orang siswa terdiri dari 7 siswa laki-laki dan 5 siswa perempuan.

Desain penelitian ini adalah desain penelitian tindakan kelas yang terdiri atas dua siklus. Tiap siklus dilaksanakan dua kali pertemuan yang sesuai dengan perubahan yang ingin dicapai. Menurut Wardani (2003: 21), langkah dalam PTK merupakan suatu daur atau siklus yang terdiri dari: (1) perencanaan (planning), (2) pelaksanaan tindakan (action), (3) evaluasi (observation and evaluation), (4) refleksi (reflection). 
Jenis Data dalam penelitian ini adalah data kuantitatif berupa tes hasil belajar dan data kualitatif berupa pelaksanaan pembelajaran yang diambil melalui lembar observasi.

Analisis data yang digunakan dalam Penelitian Tindakan Kelas (PTK) ini adalah menggunakan statistik deskriptif untuk menghitung nilai siswa, rata-rata nilai siswa, ketuntasan belajar, keberhasilan aktivitas mengajar guru dan keberhasilan aktivitas belajar siswa. Langkah-langkah analisis data adalah sebagai berikut:

a. Menentukan nilai siswa ditentukan skor yang diperoleh siswa pada tes yang dilakukan dengan rumus :

Nilai Siswa $=\frac{\text { Skor perolehan }}{\text { Skor Maksimum }} \times 100$

b. Menghitung persentase ketuntasan belajar dengan menggunakan rumus sebagai berikut :

1. Ketuntasan individu siswa ditentukan berdasarkan nilai yang diperoleh pada setiap siklus. Siswa dikatakan tuntas jika nilai yang diperoleh siswa adalah $\geq 70$ sesuai KKM yang telah ditetapkan oleh sekolah.

2. Ketuntasan klasikal

Secara klasikal, digunakan rumus:

jumlah siswa yg memperoleh nilai $\geq 70$

jumlah siswa yang mengikuti tes

(Usman dalam Majid, 2014: 41)

c. Menentukan rata - rata Nilai Siswa

Rata-rata $=\frac{\text { Jumlah nilai seluruh siswa }}{\text { Jumlah siswa }}$

(Ahmad Rohani dalam Irnawati, 2015: 31)

d. Menentukan keberhasilan aktivitas mengajar guru dan belajar siswa

$=\frac{\text { Jumlah perolehan siswa }}{\text { Jumlah skor maksimum }} \times 100 \%$

(Ahmad Rohani dalam Irnawati, 2015: 31)

Indikator kinerja dalam penelitian ini adalah indikator tentang keterlaksanaan skenario pembelajaran dan indikator peningkatan hasil belajar PKn siswa dalam penelitian ini. Setiap siswa dikatakan tuntas belajarnya (ketuntasan individu) jika proposisi jawaban benar siswa $\geq 70$. Suatu kelas dikatakan tuntas belajarnya (secara klasikal) jika dalam kelas tersebut $\geq 80 \%$ siswa yang telah tuntas belajarnya sesuai dengan KKM yang telah ditetapkan sekolah. Ketuntasan aktivitas mengajar guru dan ketuntasan aktivitas belajar siswa dianggap berhasil apabila dalam pelaksanaan pembelajaran skenario pembelajaran mencapai minimal $80 \%$ dari keseluruhan skenario pembelajaran

\section{HASIL PENELITIAN DAN PEMBAHASAN Hasil Penelitian}

Penelitian ini dilaksanakan dalam dua siklus dimana setiap siklus terdiri dari dua kali pertemuan dalam satu minggu. Siklus I pertemuan 1 dilaksanakan pada hari Senin, 15 Februari 2016 dengan sub bab materi mengenal bentuk-bentuk keputusan bersama.

Berdasarkan hasil observasi aktivitas guru keterlaksanaan skenario pembelajaran yang telah disusun pada siklus I pertemuan 1 yaitu $84,21 \%$ dan pertemuan 2 dilaksanakan pada hari Rabu, 17 Februari 2016 dengan ketrelaksanaan skenario pembeajaran sebesar $84,21 \%$. Siklus II pertemuan 1 dilaksanakan pada hari Senin, 22 Februari 2016. Pada pelaksanaan tindakan siklus II, guru telah memperbaiki kekurangan-kekurangan pada siklus I secara maksimal.

Berdasarkan hasil observasi aktivitas guru pada siklus II pertemuan 1 yaitu $89,47 \%$ dan pada siklus II pertemuan 2 sebesar $94,73 \%$. Dalam siklus I dan siklus II, observer mengamati aktivitas siswa mulai kegiatan awal pembelajaran sampai akhir pembelajaran. Berdasarkan hasil observasi aktivitas siswa, pada siklus I pertemuan 1 diperoleh sebesar $81,81 \%$ kemudian pada siklus I pertemuan 2 sebesar $81,81 \%$. Sedangkan pada siklus II pertemuan 1 diperoleh sebesar 90,90\% dan pada siklus II pertemuan 2 sebesar 90,90\%.

Pada setiap akhir siklus dilakukan evaluasi atau tes hasil belajar dengan tujuan untuk melihat sejauh mana penguasaan materi yang telah dipelajari oleh siswa. Dari hasil evaluasi pada siklus I yang dilaksanakan pada hari Sabtu, 20 Februari 2016 ketuntasan secara klasikal mencapai $58,33 \%$ dengan nilai ratarata 69,58. Ketuntasan ini belum mencapai indikator keberhasilan dalam penelitian yaitu sebesar $80 \%$. Hasil belajar siswa pada siklus II yang dilaksanakan pada hari Rabu, 24 Februari 2016, dengan tingkat ketuntasan siswa 
memperoleh nilai sebesar $83,33 \%$ dengan nilai rata-rata sebesar 81,66 menunjukkan adanya peningkatan. Hasil penelitian menunjukkan bahwa dari segi hasil belajar PKn siswa yang diperoleh pada siklus I mencapai 58,33\% atau 7 dari 12 siswa yang mendapat nilai $\geq 70$ dengan nilai rata-rata 69,58 dan pada siklus II meningkat menjadi 83,33\% atau 10 dari 12 orang siswa mendapat nilai $\geq 70$ dengan nilai rata-rata 81,66 .

Adapun presentase aktivitas mengajar guru pada siklus I pertemuan pertama sebesar $84,21 \%$ dari jumlah skor hasil aktivitas mengajar guru yaitu 16 dari 19 skor maksimal, kemudian pada pertemuan ke dua yaitu dengan nilai rata-rata $84,21 \%$ dengan skor 16 dari 19 skor maksimal. Pada siklus II pertemuan pertama memperoleh skor 17 dari 19 skor maksimal dengan nilai rata-rata $89,47 \%$ dan meningkat pada pertemuan ke dua dengan skor 18 dari 19 skor maksimal dengan rata-rata $94,73 \%$.

Sedangakan presentase aktivitas belajar siswa pada siklus I pertemuan pertama sebesar $81,81 \%$ dengan skor 9 dari 11 skor maksimal kemudian pada pertemuan ke dua dengan persentase sebesar $81,81 \%$ dengan skor 9 dari 11 skor maksimal. Dan pada siklus II pertemuan pertama memperoleh skor 10 dari 11 skor maksimal dengan rata-rata $90,90 \%$ kemudian pada pertemuan ke dua menjadi 10 dari 11 skor maksimal dengan persentase sebesar 90,90\%.

Tabel 1. Analisis Ketuntasan Hasil Belajar Siswa Pada Siklus I

\begin{tabular}{|c|c|c|c|c|}
\hline No & Ketuntasan & Skor & $\begin{array}{c}\text { Jumlah } \\
\text { siswa }\end{array}$ & $\begin{array}{c}\text { Persentase } \\
(\%)\end{array}$ \\
\hline 1 & Tuntas & $70-100$ & 7 & $58,33 \%$ \\
\hline 2 & $\begin{array}{c}\text { Belum } \\
\text { Tuntas }\end{array}$ & $0-69$ & 5 & $41,67 \%$ \\
\hline \multicolumn{2}{|l|}{ Total } & & 12 & $100 \%$ \\
\hline
\end{tabular}

Berdasarkan hasil observasi pada siklus I, guru dan siswa telah melakukan sebagian kegiatan pembelajaran dengan baik.Namun demikian, masih terdapat kekurangankekurangan yang perlu diperbaiki antara lain, guru kurang memberikan motivasi kepada siswa untuk serius dalam mengikuti kegiatan pembelajaran.
Hasil analisis ketuntasan belajar siswa pada penelitian hasil belajar secara klasikal dapat dilihat pada tabel berikut ini:

Tabel 2. Analisis Ketuntasan Hasil Belajar Siswa Pada Siklus II

\begin{tabular}{|c|c|c|c|c|}
\hline No & $\begin{array}{c}\text { Ketunta } \\
\text { san }\end{array}$ & Skor & $\begin{array}{c}\text { Jumlah } \\
\text { siswa }\end{array}$ & $\begin{array}{c}\text { Persentase } \\
(\%)\end{array}$ \\
\hline 1 & Tuntas & $70-100$ & 10 & $83,33 \%$ \\
\hline 2 & $\begin{array}{c}\text { Belum } \\
\text { Tuntas }\end{array}$ & $0-69$ & 2 & $16,67 \%$ \\
\multicolumn{2}{|l|}{ Total } & 12 & $100 \%$ \\
\hline \multicolumn{3}{|c|}{ Dari hasil tes belajar siswa yang }
\end{tabular}

diperoleh pada siklus II, dapat dikatakan bahwa penerapan model pembelajaran kooperatif tipe TPS memberikan dampak yang positif terhadap hasil belajar siswa. Hal ini sejalan dengan pendapat yang menyatakan bahwa model pembelajaran kooperatif adalah rangkaian kegiatan belajar yang dilakukan oleh siswa dalam kelompok-kelompok tertentu untuk mencapai tujuan pembelajaran yang telah dirumuskan (Mohamad Syarif Sumantri, 2015, p.49).

Indikator keberhasilan dalam penelitian ini telah tercapai, dalam hal ini minimal $80 \%$ siswa telah mencapai nilai $\geq 70$, maka penelitian ini dihentikan sampai pada siklus II. Ini berarti bahwa, hipotesis tindakan telah terjawab yaitu dengan melalui penerapan model pembelajaran kooperatif tipe TPS hasil belajar PKn siswa pada materi Menghargai dan Menaati Keputusan Bersama kelas V SDN 7 Kabangka Kabupaten Muna dapat ditingkatkan.

\section{Pembahasan}

Berdasarkan hasil observasi aktivitas guru keterlaksanaan skenario pembelajaran yang telah disusun pada siklus I pertemuan 1 yaitu $84,21 \%$ dan pertemuan 2 dilaksanakan pada hari Rabu, 17 Februari 2016 dengan ketrelaksanaan skenario pembeajaran sebesar $84,21 \%$. Siklus II pertemuan 1 dilaksanakan pada hari Senin, 22 Februari 2016. Pada pelaksanaan tindakan siklus II, guru telah memperbaiki kekurangan-kekurangan pada siklus I secara maksimal. Berdasarkan hasil observasi aktivitas guru pada siklus II pertemuan 1 yaitu $89,47 \%$ dan pada siklus II pertemuan 2 sebesar $94,73 \%$. 
Dalam siklus I dan siklus II, observer mengamati aktivitas siswa mulai kegiatan awal pembelajaran sampai akhir pembelajaran. Berdasarkan hasil observasi aktivitas siswa, pada siklus I pertemuan 1 diperoleh sebesar $81,81 \%$ kemudian pada siklus I pertemuan 2 sebesar $81,81 \%$. Sedangkan pada siklus II pertemuan 1 diperoleh sebesar $90,90 \%$ dan pada siklus II pertemuan 2 sebesar 90,90\%.

Jika dihubungkan dengan pendapat para ahli salah satunya yaitu menurut Hamalik (2008: 30) bahwa belajar merupakan langkahlangkah atau prosedur yang ditempuh untuk mencapai tujuan. Bukti bahwa seseorang telah belajar adalah terjadinya perubahan tingkah laku pada orang tersebut, misalnya dari tidak tahu menjadi tahu, dan dari tidak mengerti menjadi mengerti. Maka dapat disimpulkan bahwa aktivitas belajar siswa dapat ditingkatkan melalui penerapan model pembelajaran Kooperatif tipe TPS materi pokok Menghargai dan Menaati Keputusan Bersama ini.

Menurut Sudjana dalam Rahmawati (2010: 10) hasil belajar adalah kemampuan yang dimiliki siswa setelah ia menerima pengalaman belajarnya. Hasil belajar merupakan perubahan indikator perubahan yang terjadi pada individu setelah mengalami proses belajar mengajar, dimana untuk untuk mengungkapkannya biasanya menggunakan suatu alat penilaian yang dibuat oleh guru seperti, tes evaluasi.

Pada setiap akhir siklus dilakukan evaluasi atau tes hasil belajar dengan tujuan untuk melihat sejauh mana penguasaan materi yang telah dipelajari oleh siswa. Dari hasil evaluasi pada siklus I yang dilaksanakan pada hari Sabtu, 20 Februari 2016 ketuntasan secara klasikal mencapai 58,33\% dengan nilai ratarata 69,58. Ketuntasan ini belum mencapai indikator keberhasilan dalam penelitian yaitu sebesar $80 \%$. Rendahnya hasil belajar siswa pada siklus I disebabkan adanya beberapa siswa yang kurang aktif dalam berkomunikasi secara efektif dengan pasangan dalam kelompoknya sehingga siswa tersebut belum berani untuk menanggapi ide atau jawaban yang dihasilkan oleh kelompok lain dan itu sangat mempengaruhi hasil belajar.

Melihat rendahnya hasil belajar siswa pada siklus I, maka guru dan observer berdiskusi untuk melanjutkan ke tahap selanjutnya yaitu siklus II. Beberapa kekurangan yang ada pada siklus I kemudian direfleksi dan dilakukan perbaikan untuk pelaksanaan tindakan siklus II, sehingga pada pelaksanaan pembelajaran dapat berjalan dengan baik serta memperoleh hasil yang maksimal dan lebih baik dari sebelumnya. Hal ini dapat dilihat dari hasil belajar siswa pada siklus II yang dilaksanakan pada hari Rabu, 24 Februari 2016, dengan tingkat ketuntasan siswa $83,33 \%$ dengan nilai rata-rata sebesar 81,66 menunjukkan adanya peningkatan.

Pada siklus II penerapan model pembelajaran Kooperatif tipe TPS terlaksana dengan baik dan maksimal. Meningkatnya hasil belajar siswa karena siswa sudah memahami model pembelajaran yag digunakan dan sudah mampu menanggapi ide atau jawaban dari temannya sehingga komunikasi yang dilakukan antar anggota kelompok sudah efektif. Berdasarkan hasil analisis ketuntasan hasil belajar siswa, maka model pembelajaran Kooperatif tipe TPS dapat meningkatakan hasil belajar siswa khususnya pada materi Menghargai dan Menaati Keputusan Bersama kelas V SD Negeri 7 Kabangka.

Dari data yang diperoleh peneliti setelah melakukan penelitian selama 2 siklus (4 kali pertemuan) membuktikan bahwa model pembelajaran kooperatif tipe TPS dapat meningkatkan kegiatan aktivitas mengajar guru dan aktivitas belajar siswa SD Negeri 7 Kabangka Kabupaten Muna dan member dampak yang sangat baik, bahkan sebagian besar siswa sudah berani mengeluarkan pendapatnya dengan baik.

Hal tersebut ditegaskan kembali oleh Lyman (Daryanto, 2014: 38), model pembelajaran TPS membantu para siswa untuk mengembangkan pemahaman konsep dan materi pelajaran, mengembangkan kemampuan untuk berbagi informasi dan menarik kesimpulan, serta mengembangkan kemampuan untuk mempertimbangkan nilainiali lain dari suatu materi pelajaran.

\section{Simpulan}

Berdasarkan hasil penelitian dan pembahasan, maka dapat disimpulkan bahwa dari segi hasil belajar PKn siswa yang diperoleh pada siklus I mencapai 58,33\% atau 7 dari 12 siswa yang mendapat nilai $\geq 70$ dengan nilai rata-rata 69,58 dan pada siklus II 
meningkat menjadi $83,33 \%$ atau 10 dari 12 orang siswa mendapat nilai $\geq 70$ dengan nilai rata-rata 81,66.

Persentase aktivitas mengajar guru pada siklus I pertemuan pertama sebesar $84,21 \%$ kemudian pada pertemuan. Pada siklus II pertemuan pertama memperoleh nilai rata-rata $89,47 \%$ dan meningkat pada pertemuan ke dua dengan rata-rata $94,73 \%$.

Sedangakan presentase aktivitas belajar siswa pada siklus I pertemuan pertama sebesar $81,81 \%$ kemudian pada pertemuan ke dua dengan persentase sebesar $81,81 \%$. Dan pada siklus II pertemuan pertama memperoleh nilai dengan rata-rata $90,90 \%$ kemudian pada pertemuan ke dua menjadi $90,90 \%$.

\section{DAFTAR PUSTAKA}

Irnawati. 2015. Meningkatkan hasil belajar PKn pada materi keputusan bersama melalui penerapan model pembelajaran Kooperatif tipe TPS pada siswa kelas V SD Negeri Totombe Jaya Kecamatan Sampara. SKRIPSI. Kendari: Universitas Halu OleoAgung, Iskandar. 2012. Menghasilkan Guru Kompeten \&

Profesional. Jakarta: Bee Media Indonesia.

Fathurrohman, pupuh dan sobry sutikno. 2007.

Strategi Belajar Mengajar Melalui Penanaman Konsep Umum Dan Konsep Islami. Bandung : PT. Refka aditama.

Oemar, Hamalik. 2001. Proses Belajar Mengajar. Jakarta: PT Bumi Aksara.

Paizaludin, Ermalinda. 2013. Penelitian Tindakan Kelas. Bandung: Alfabeta.

Sudjana, Nana. 2009. Penilaian Hasil Proses Belajar Mengajar. Bandung: PT Remaja Rosdakarya.

Trianto. 2007. Model-model Pembelajaran Inovatif Beriorentasi Konstruktivistik. Jakarta: Prestasi Pustaka. 